\title{
Hepatoprotective potentials of methanol extract of $T$. conophorum seeds of carbon tetrachloride induced liver damage in Wistar rats
}

\author{
Kelly Oriakhi ${ }^{*}$, Patrick O. Uadia ${ }^{2}$ and Ikechi G. Eze ${ }^{3}$
}

\begin{abstract}
Background: Tetracarpidium conophorum (TC) is a tropical plant used in ethno medicine for treating various diseases including hepatic ailments. The present study investigated the effect of methanol extract of $T$. conophorum seeds in rats intoxicated with $\mathrm{CCl}_{4} 24 \mathrm{~h}$ and $48 \mathrm{~h}$ after intoxication respectively.

Methods: Thirty-five male Wistar rats were distributed equally into seven groups. Group IA (control) received distilled water and olive oil (i.p), group IIA rats were intoxicated with $\mathrm{CCl}_{4}$ in olive oil $(600 \mathrm{mg} / \mathrm{kg}$, i.p.) only on the 8th day, while groups IIIA, IVA and VA were given $100 \mathrm{mg} / \mathrm{kg}$ of sylimarin, $250 \mathrm{mg} / \mathrm{kg}$ and $500 \mathrm{mg} / \mathrm{kg}$ of methanol extract respectively for 7 days, thereafter they were intoxicated with $\mathrm{CCl}_{4}$ on the 8th day. Groups VIA and VIIA were intoxicated with $\mathrm{CCl}_{4}$ on the 8th day and administered $250 \mathrm{mg} / \mathrm{kg}$ and $500 \mathrm{mg} / \mathrm{kg}$ of methanol extract of $T$. conophorum seeds at $1 \mathrm{~h}, 6 \mathrm{~h}, 12 \mathrm{~h}, 18 \mathrm{~h}$ and $24 \mathrm{~h}$ and the animals were sacrificed $24 \mathrm{~h}$ after intoxication with $\mathrm{CCl}_{4}$. This procedure was repeated for a different set of thirty-five (groups IB-VIIB) male rats but the animals were sacrificed $48 \mathrm{~h}$ after intoxication with $\mathrm{CCl}_{4}$. Fasting blood sample was collected by cardiac puncture for biochemical analyses.
\end{abstract}

Results: There were significant increases $\left(p^{<} 0.05\right)$ in serum hepatic enzyme markers (ALT, AST, ALP, and $y-G T$ ) activities, as well as bilirubin and significant reduction in antioxidant enzymes ( $\left.\mathrm{P}^{\circ} 0.05\right)$ in rats intoxicated with $\mathrm{CCl}_{4}$ when compared to control group, but administration (pre-treatment and post-treatment) of methanol extract of $T$. conophorum seeds at doses of 250 and $500 \mathrm{mg} / \mathrm{kg}$ body weight and standard sylimarin drug attenuated the toxic insult of $\mathrm{CCl}_{4}$ in a dose-dependent manner at $24 \mathrm{~h}$ and $48 \mathrm{~h}$ after intoxication respectively.

Conclusions: Our findings confirm that methanol extract of TC exhibited hepatoprotective activity against $\mathrm{CCl}_{4}$ induced liver damage.

Keywords: African walnut, Liver damage, Hepatoprotection and carbon tetrachloride, Antioxidant

\section{Background}

Liver disease is a main cause of death in many developing countries. It is an organ of prime importance and plays a significant role not only in metabolism and detoxification of exogenous toxins and therapeutic agents but also in the bio-regulation of fats, carbohydrates,

\footnotetext{
* Correspondence: kelly.oriakhi@uniben.edu

'Department of Medical Biochemistry, School of Basic Medical Sciences,

University of Benin, Benin City, Nigeria

Full list of author information is available at the end of the article
}

amino acids, proteins, blood coagulation and immunomodulation [1]. However, impairment of the liver generally occurs from excessive exposure to toxicants, alcohol, chemotherapeutic agents, viruses and protozoan infections [1]. An experimental model to induce liver damage by carbon tetrachloride $\left(\mathrm{CCl}_{4}\right)$ has been established. $\mathrm{CCl}_{4}$ is activated by cytochrome (CYP) $2 \mathrm{E} 1, \mathrm{CYP} 2 \mathrm{~B} 1$ or CYP2B2, and possibly CYP3A, to form the trichloromethyl radical, $\mathrm{CCl}_{3}{ }^{-}[2]$. This radical can bind to cellular molecules (nucleic acid, protein, lipid), impairing crucial cellular processes such as lipid metabolism, which 
results in fatty degeneration (steatosis) $[3] . \mathrm{CCl}_{3}{ }^{-}$forms adducts with DNA, which initiate the onset of hepatocellular carcinoma. This radical can also react with oxygen to form the trichloromethylperoxy radical $\mathrm{CCl}_{3} \mathrm{OO}^{-}$, a highly reactive species. $\mathrm{CCl}_{3} \mathrm{OO}^{-}$reacts with polyunsaturated fatty acids and phospholipids to initiates the chain reaction of lipid peroxidation. This affects the permeabilities of mitochondrial, endoplasmic reticulum, and plasma membranes, resulting in the loss of cellular calcium sequestration and homeostasis, which can contribute heavily to subsequent cell damage $[4,5]$. Among the degradation products of fatty acids are reactive aldehydes, especially 4-hydroxynonenal, which bind easily to functional groups of proteins and inhibit important enzyme activities (loss of glucose-6-phosphatase activation) [6] thereby leading to liver injury [7]. $\mathrm{CCl}_{4}$ intoxication is mediated by two types of nonparenchymal liver cells, viz.; Kupffer cells and stellate cells. The activation of Kupffer cells by $\mathrm{CCl}_{4}$ mediate inflammatory processes via the nuclear factor kappa B (NF-kB) signal transduction pathway with production of pro-inflammatory cytokines such as tumor necrosis factor- $\alpha$ (TNF- $\alpha$ ), interleukin-1 $\beta$ (IL-1 $\beta)$, interleukin-6(IL-6) and other inflammatory mediators; inducible nitric oxide synthase (iNOS), and cyclooxygenase-2 (Cox-2) $[8,9]$, which in turn causes full activation of the mitogen activated protein kinase (MAPK)/extracellular signal-related kinase (ERK) and the Janus kinase (Jak)-signal transducer and activator of transcription protein (STAT) pathway. These pathways are involved in the regulation of cell proliferation and apoptosis [10]. Stellate cells, are normally quiescent and fat-storing cells, but after activation by agents such as $\mathrm{CCl}_{4}$, it display a typical acute-phase response [11], take on a fibroblast like appearance, release nitric oxide, begin to overproduce type-I collagen, and thus promote hepatic fibrosis [12].

However, there are current orthodox drugs for managing/treating hepatic diseases, but these drugs have adverse side effects, and resistance to many of them can develop after variable time periods [13]. To circumvent this challenge, our present study is designed to use alternative medicine (phytotherapy) in the treatment of liver disease. Medicinal plants have always been rich sources of biologically active compounds vital to human health [14]. Thus a search for a new molecule with hepatoprotective properties from plants could be a useful strategy [15]. One of such plants is T. conophorum (African walnut) which belongs to the family of Euphorbiaceae and it is commonly known in Southern Nigeria as ukpa (Igbo), in Western Nigeria as awusa or asala (Yoruba) and okhue in Bini [16]. Isolation and structural elucidation of phytochemicals such as steroidal terpenoids, flavonoids, and phenols from $T$. conophorum seed have been reported by our research group (data not provided). This plant possesses multiple medicinal properties such as antioxidant and immunostimulatory properties [17], improve fertility, antimicrobial [18] and anticancer activities [19]. It is against this background that this research seeks to evaluate the hepatoprotective effect of the methanol extract of $T$. conophorum seeds.

\section{Methods \\ Collection of plant materials}

The seeds of T. conophorum used in this study were collected from an open forest at Ovia North East Local government Area of Edo state, Nigeria. The fresh walnut seeds were identified by Professor M.E. Osawaru and authenticated by Professor MacDonald Idu both of the Department of Plant Biology and Biotechnology of the University of Benin, Benin City, Nigeria. Herbarium specimen (voucher number UBHe0153) was deposited at the Herbarium of the University of Benin.

\section{Extract preparation}

Air-dried and powdered seeds of T. conophorum (1 kg) were extracted with absolute methanol $(5 \mathrm{~L})$ at room temperature for $72 \mathrm{~h}$. The samples were filtered with Whatman No. 50 filter paper and the filtrate evaporated to dryness with a rotary evaporator (RE 300, Bibby Scientific, UK) to give $320 \mathrm{~g}$. The resultant yield was stored in an air-tight container and kept in the refrigerator maintained at $4{ }^{\circ} \mathrm{C}$.

\section{Chemicals}

Carbon tetrachloride $\left(\mathrm{CCl}_{4}\right)$, 1-chloro-2,4-dinitrobenzene (CDNB), 5',5' -dithiobis-2-nitrobenzoic acid (DTNB), reduced glutathione (GSH), epinephrine, hydrogen peroxide $\left(\mathrm{H}_{2} \mathrm{O}_{2}\right)$, trichloroacetic acid (TCA), and thiobarbituric acid (TBA) were purchased from Sigma (St. Louis, MO, USA). Alanine aminotransferase (ALT) kit, aspartate aminotransferase kit, g-glutamyl transferase (g-GT) kit, total bilirubin, total protein and alkaline phosphatase kit were obtained from Randox laboratories Ltd. (Admore, Crumlin, Co-Antrim, UK). All other reagents were of analytical grade and were obtained from BDH (Poole, Dorset, UK).

\section{Animals}

Albino rats (Wistar strain) (150-170 g), bred in the Department of Biochemistry, Faculty of Life Science, University of Benin, Benin City, Nigeria, were used for the study. They were kept in clean cages in a $12 \mathrm{~h}$ light/dark cycle with litter changed daily. The animals were housed in galvanized rat cages and acclimatized for two weeks before the commencement of the experiment. They were fed with guinea growers' mash and had access to water ad libitum. Experiments were performed according to guidelines for the care and use of laboratory animals. Weights of the rats were monitored throughout the period of the experiment. The handling of the animals 
was in accordance with the principles of laboratory animal care [20].

\section{Experimental design}

Effect of methanol extract of $T$. conophorum seeds on rats intoxicated with carbon tetrachloride after $24 \mathrm{~h}$ of intoxication. Thirty-five (35) albino rats (Wistar strain) of average weight $150 \pm 10 \mathrm{~g}$ were used in this study, with 5 rats per group.

Group IA (control): Rats were administered olive oil (i.p) on the 8th day and distilled water only (orally).

Group IIA: Rats were administered carbon tetrachloride $\left(\mathrm{CCl}_{4}\right)$ in olive oil $(600 \mathrm{mg} / \mathrm{kg}$, i.p $)$ on the 8 th day.

Group IIIA: Rats were given silymarin $(100 \mathrm{mg} / \mathrm{kg}$ body weight) daily for 1 week orally, then on the 8 th day, the rats were intoxicated with $\mathrm{CCl}_{4}$ in olive oil $(600 \mathrm{mg} / \mathrm{kg}$, i.p), fasted overnight, thereafter fasting blood samples were collected after $24 \mathrm{~h}$ of intoxication of $\mathrm{CCl}_{4}$.

Groups IVA\&VA: Rats were given methanol extract of T. conophorum seed (250 and $500 \mathrm{mg} / \mathrm{kg}$ body weight, respectively) daily for 1 week orally, then on the 8th day, the rats were intoxicated with $\mathrm{CCl}_{4}$ in olive oil $(600 \mathrm{mg} /$ $\mathrm{kg}$, i.p), fasted over night, thereafter blood samples were collected after $24 \mathrm{~h}$ of intoxication with $\mathrm{CCl}_{4}$.

Groups VIA\&VIIA: Rats were administered carbon tetrachloride $\left(\mathrm{CCl}_{4}\right)$ in olive oil $(600 \mathrm{mg} / \mathrm{kg}$, i.p), and then given methanol extract of T. conophorum seed (250 and $500 \mathrm{mg} / \mathrm{kg}$ body weight respectively, orally) at $1 \mathrm{~h}, 6 \mathrm{~h}$, $12 \mathrm{~h}, 18 \mathrm{~h}$ and $24 \mathrm{~h}$. Fasting blood samples were collected after the last administration of the extract at $24 \mathrm{~h}$.

Effect of methanol extract of $T$. conophorum seeds intoxicated with carbon tetrachloride after $48 \mathrm{~h}$ of intoxication. Thirty (35) albino rats (Wistar strain) of average weight $150 \pm 10 \mathrm{~g}$ were used in this study, with 5 rats per group.

Group IB (control): Rats were administered olive oil (i.p) on the 8th day and distilled water only (orally).

Group IIB: Rats were administered CCl4 in olive oil $600 \mathrm{mg} / \mathrm{kg}$ (i.p) on the 8th day.

Group IIIB: Rats were given silymarin $(100 \mathrm{mg} / \mathrm{kg}$ body weight) daily for 1 week orally, then on the 8th day, the rats were intoxicated with $\mathrm{CCl}_{4}$ in olive oil $(600 \mathrm{mg} / \mathrm{kg}$, i.p), thereafter fasting blood samples were collected after $48 \mathrm{~h}$ of intoxication with $\mathrm{CCl}_{4}$.

Groups IVB\&VB: Rats were given methanol extract of T. conophorum seed $(250$ and $500 \mathrm{mg} / \mathrm{kg}$ body weight, respectively) daily for 1 week orally, then on the 8th day, the rats were intoxicated with $\mathrm{CCl} 4$ in olive oil $(600 \mathrm{mg} /$ $\mathrm{kg}$, i.p), thereafter fasting blood samples were collected after $48 \mathrm{~h}$ of intoxication with $\mathrm{CCl}_{4}$.

Groups VIB\&VIIB: Rats were administered $\mathrm{CCl}_{4}$ in olive oil $(600 \mathrm{mg} / \mathrm{kg}$, i.p), and then given methanol extract of T. conophorum seed (250 and $500 \mathrm{mg} / \mathrm{kg}$ body weight respectively, orally) at $1 \mathrm{~h}, 6 \mathrm{~h}, 12 \mathrm{~h}, 18 \mathrm{~h}$ and $24 \mathrm{~h}$. Fasting blood samples were collected after the last administration of the extract at $48 \mathrm{~h}$ of intoxication with $\mathrm{CCl}_{4}$.

\section{Blood sample collection}

Twenty-four and $48 \mathrm{~h}$ after the last treatment of groups $A$ and $B$ respectively, rats were killed by cervical dislocation and dissected. The livers were quickly removed and rinsed in ice-cold $1.15 \% \mathrm{KCl}$, dried and weighed. The livers were then minced with scissors in 4 volumes of ice-cold $0.1 \mathrm{M}$ phosphate buffer, pH 7.4 and homogenized in a Potter-Elvehjem homogenizer. The homogenates were later centrifuged at $12,000 \mathrm{~g}$ for $15 \mathrm{~min}$ at $4^{\circ}$ $\mathrm{C}$ to obtain post-mitochondrial fraction (PMF). Blood was collected from the heart by the heart puncture technique into sample tubes. The blood samples were centrifuged at $3000 \mathrm{~g}$ for $10 \mathrm{~min}$ in a bench centrifuge to obtain serum, which was later used for the estimation of biochemical parameters.

\section{Determination of hepatic enzymes}

Alanine aminotransferase and aspartate aminotransferase (AST) were determined using the method of Reitman and Frankel [21]. For determination of ALT activity, the serum sample was added to the buffered solution containing DL-alanine and $\alpha$-ketoglutarate $(\mathrm{pH}$ 7.4) and incubated for $30 \mathrm{~min}$ at $37^{\circ} \mathrm{C}$. After incubation $1.0 \mathrm{mM}$, DNPH was added, followed by the addition of $0.4 \mathrm{M}$ $\mathrm{NaOH}$. The absorbance was read at $500 \mathrm{~nm}$ and the ALT activity deduced, while in AST activity; the serum sample was added to the buffered solution containing L-aspartic and $\alpha$-ketoglutarate $(\mathrm{pH}$ 7.4) and incubated for $1 \mathrm{~h}$ at room temperature. After incubation $1.0 \mathrm{mM}$, DNPH was added, followed by the addition of $0.4 \mathrm{M}$ $\mathrm{NaOH}$ and absorbance read at $500 \mathrm{~nm}$. For determination of $\gamma$-GT activity [22] the serum sample was added to a substrate solution containing glycylglycine, $\mathrm{MgCl}$, and $\gamma$-glutamyl-p-nitroanilide in $0.05 \mathrm{M}$ Tris (free base) $\mathrm{pH}$ 8.2. The mixture was incubated at $37{ }^{\circ} \mathrm{C}$ for $1 \mathrm{~min}$ and absorbance read at $405 \mathrm{~nm}$ at $1 \mathrm{~min}$ interval for 5 min. The activity of $\gamma$-GT was calculated from the absorbance value using the formula.

ALP activity was determined using Teco kit and method described by Kochmar and Moss, [23], precisely $0.5 \mathrm{ml}$ of alkaline phosphatase substrate was placed into test tubes and equilibrated for $3 \mathrm{~min}$ at $37^{\circ} \mathrm{C}$. At the timed interval, $0.05 \mathrm{ml}$ for each standard, control, and the sample was added to their respective test tubes, mix gently and incubate for 10 mins at $37^{\circ} \mathrm{C}$. Alkaline phosphatase color developer $(2.5 \mathrm{ml})$ was added to the respective test tubes and absorbance read at $590 \mathrm{~nm}$. 


\section{Determination of Total protein}

Total protein was determined using Radox kit and described by Tietz, [24].

\section{Determination of Total bilirubin}

Total bilirubin was determined using Radox kit and described by Tietz Jendrassik and Grof [25].

\section{Determination of oxidative stress parameters}

\section{Superoxide dismutase (SOD) activity}

The level of SOD activity was determined according to the method of Misra and Fridovich, [26]. The liver fraction was reacted with epinephrine solution and the rate of inhibition of adrenochrome solution from the autooxidation of epinephrine was measured spectrophotometrically at $480 \mathrm{~nm}$.

\section{Catalase activity}

Catalase activity in the liver was determined as previously described by Asru [27]. The liver fraction was added to $0.2 \mathrm{M} \mathrm{H}_{2} \mathrm{O}_{2}$ solution and samples of this mixture were withdrawn at various intervals into a dichromate/acetic acid buffered solution. The rate of decomposition of hydrogen peroxide was determined spectrophotometrically at $480 \mathrm{~nm}$.

\section{Reduced glutathione}

The determination of reduced glutathione (GSH) level of tissue was based on the measurement of the absorbance of 2 nitro 5-thiobenzoic acid formed, at $412 \mathrm{~nm}$ [28], when Ellman's reagent reacted with GSH. An aliquot of the liver fraction was deproteinized in $4 \%$ sulphosalicylic acid and centrifuged at $17,000 \mathrm{rpm}$ for $15 \mathrm{~min}$ at $4{ }^{\circ} \mathrm{C}$. The supernatant was reacted with Ellman's reagent and the absorbance of the complex formed read at $412 \mathrm{~nm}$. The amount of GSH in the liver fraction was determined from a standard GSH calibration curve.

\section{Glutathione-S-transferase activity}

The activity of GST in the liver fraction was determined as described by Habig et al. [29]. The $1.0 \mathrm{mM} \mathrm{GSH}$ and $1.0 \mathrm{nM}$ CDNB were reacted with the tissue fraction and the change in optical density at $340 \mathrm{~nm}$ within $30 \mathrm{~s}$ intervals for 3 min was taken. The activity was calculated with an extinction coefficient of $9.6 \mathrm{mM} / \mathrm{cm}$.

\section{Glutathione peroxidase activity}

The activity of glutathione peroxide (GPx) was determined by the method described by Rotruck et al. [30]. The mixture containing $0.5 \mathrm{ml}$ of sodium phosphate buffer, $0.1 \mathrm{ml}$ of $10 \mathrm{mM}$ sodium azide, $0.2 \mathrm{ml}$ of $4 \mathrm{mM}$ reduced glutathione, $0.1 \mathrm{ml}$ of $2.5 \mathrm{mM}$ Hydrogen peroxide (H2O2) was performed. Precisely $0.5 \mathrm{ml}$ of the sample was taken from the mixture into test tubes and was incubated at $37{ }^{\circ} \mathrm{C}$ for $3 \mathrm{~min}$ and the reaction was terminated using $0.5 \mathrm{ml}$ TCA (10\%). The mixture was centrifuged to obtain the supernatant and thereafter $1 \mathrm{ml}$ of the DNTB reagent was added to developed the colour, and absorbance read at $412 \mathrm{~nm}$ using a spectrophotometer. The enzyme activity was expressed as Units/mg protein (one unit is the amount of enzyme that converts $1 \mathrm{~mol}$ GSH to GSSG in the presence of hydrogen peroxide/min).

\section{Determination of lipid peroxidation}

Lipid peroxidation was assessed in terms of malondialdehyde (MDA) formation in the rat liver 10,000 g supernatant fraction. The measurement of thiobarbituric acid reacting substances (TBARS) was performed as described previously by Varshney and Kale, [31]. MDA was quantitated by using $\Sigma=1.56 \times 105 \mathrm{M}^{-1} \mathrm{~cm}^{-1}$ [32].

\section{Histology}

Portions of the liver were fixed in 10\% neutral buffered formalin for histology. Thin sections of the liver were dissected and processed using Leica TP2010 automatic tissue processor for $18 \mathrm{~h}$. The processor passed the tissues through fixation, dehydration, dealcoholisation, and paraffinization. Ultra-thin sections of $5 \mu \mathrm{m}$ were sliced from the paraffinated sections using a Thermo scientific semi-automated rotary microtome. The tissues were then subjected to hematoxylin and eosin staining and viewed under a microscope using $10 \mathrm{X}$ magnification.

\section{Statistical analysis}

Data were expressed as the mean \pm S.E.M of triplicate determinations using the statistical package for social science (SPSS) version 17.0 for windows. Statistical significance was calculated by one-way analysis of variance. Differences between means were estimated by Duncan's multiple range tests.

\section{Results}

Effect of methanol extract of $T$. conophorum seeds on serum aspartate aminotransferase, alanine aminotransferase and alkaline phosphatase in $\mathrm{CCl}_{4}$ induced hepatotoxicity in rats after $\mathbf{2 4} \mathrm{h}$ of intoxication The effect of methanol extract of $T$. conophorum seeds on serum hepatic enzymes (AST, ALT, and ALP) in $\mathrm{CCl}_{4}$ induced hepatotoxicity in rats after $24 \mathrm{~h}$ of intoxication is shown in Fig. 1. Administration of $\mathrm{CCl}_{4}$ at a dose of $600 \mathrm{mg} / \mathrm{kg}$ body weight significantly increased ( $\left.\mathrm{p}^{<} 0.05\right)$ the activities of the serum enzymes AST, ALT, ALP by $65.9 \%, 61.5 \%$, 76.6\% respectively when compared with the normal control (Group IA). Pre-treatment of the rats with the methanol extract of $T$. conophorum seeds at a dose of 250 and $500 \mathrm{mg} / \mathrm{kg}$ body weight for one week before administering $\mathrm{CCl}_{4}$ showed a significant decrease $\left(p^{<} 0.05\right)$ in AST, ALT, ALP when compared to rats administered 


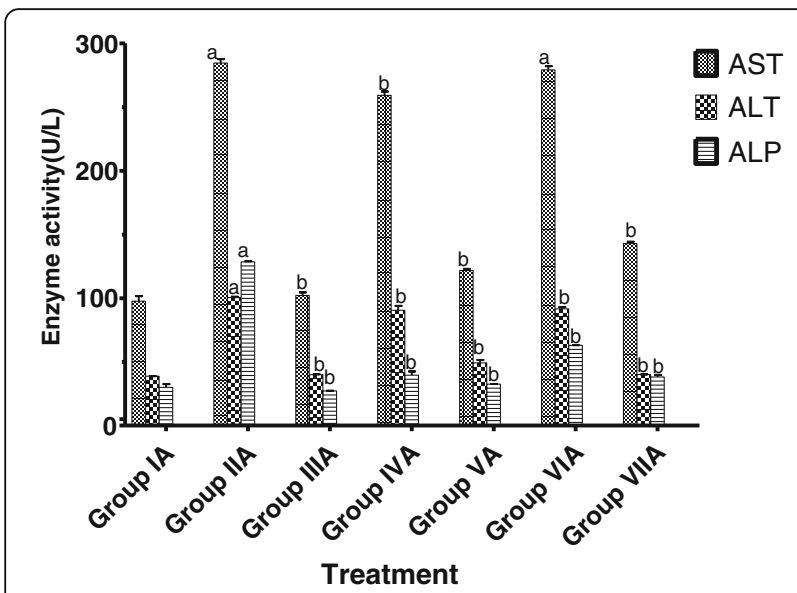

Fig. 1 Effect of methanol extract of T. conophorum seeds on serum Aspartate aminotransferase, Alanine aminotransferase and Alkaline phosphatase activities in $\mathrm{CCl}_{4}$ induced hepatotoxicity in rats after $24 \mathrm{~h}$ of intoxication. Values are Mean \pm SEM, $n=5$ rats in each group. $p<$ 0.05 , a as compared with the normal control group; b as compared with the $\mathrm{CCl}_{4}$ only (group IIA). AST- Aspartate aminotransferase; ALTAlanine aminotransferase; ALP- Alkaline phosphatase; $\mathrm{CCl}_{4}$ - Carbon tetrachloride. Group IA (control) received distilled water and olive oil (i.p), group IIA rats were intoxicated with $\mathrm{CCl}_{4}$ in olive oil $(600 \mathrm{mg} / \mathrm{kg}$, i.p.) only on the 8th day, while groups IIIA, IVA and VA were given $100 \mathrm{mg} / \mathrm{kg}$ of silymarin, $250 \mathrm{mg} / \mathrm{kg}$ and $500 \mathrm{mg} / \mathrm{kg}$ of methanol extract respectively for 7 days, thereafter intoxicated with $\mathrm{CCl}_{4}$ on the 8th day. Groups VIA and VIIA were intoxicated with $\mathrm{CCl}_{4}$ on the 8th day and administered $250 \mathrm{mg} / \mathrm{kg}$ and $500 \mathrm{mg} / \mathrm{kg}$ of methanol extract of T. conophorum seeds at $1 \mathrm{~h}, 6 \mathrm{~h}, 12 \mathrm{~h}, 18 \mathrm{~h}$ and $24 \mathrm{~h}$. Fasting blood samples were collected after the last administration of the extract at $24 \mathrm{~h}$ of intoxication with $\mathrm{CCl}_{4}$

$\mathrm{CCl}_{4}$ only (Group IIA). The standard drug silymarin at a dose of $100 \mathrm{mg} / \mathrm{kg}$ also significantly prevented the elevation of the serum enzymes. Pre-treatment for a week with the crude methanol extract (250 and $500 \mathrm{mg} / \mathrm{kg}$ ) and silymarin exhibited a protection of $8.93 \%, 57.2 \%$ and $64.1 \%$ in AST levels, 9.9\%, 51.02\% and 60.3\% in ALT levels, 66\% 74.6\%, and 78.9\% in ALP levels respectively. Post-treatment of rats with the extract after $\mathrm{CCl}_{4}$ administration at 250 and $500 \mathrm{mg} / \mathrm{kg}$ significantly restored liver damage in a dose-dependent manner.

\section{Effect of methanol extract of $T$. conophorum seeds on} gamma gtutamyl transferase and Total bilirubin in $\mathrm{CCl}_{4}$ induced hepatotoxicity in rats after $24 \mathrm{~h}$ of intoxication The effect of methanol extract of T. conophorum seeds on serum $\gamma$-GT and total bilirubin in $\mathrm{CCl}_{4}$ induced hepatotoxicity in rats after $24 \mathrm{~h}$ of intoxication is shown in Figs. 2 and 3 respectively. Administration of $\mathrm{CCl}_{4}$ at a dose of $600 \mathrm{mg}$ / $\mathrm{kg}$ body weight significantly increased $\left(p^{<} 0.05\right)$ the levels of the serum $\gamma$-GT and total bilirubin by $65.62 \%$ and $87.1 \%$ respectively when compared with the normal control (Group IA). Pre-treatment of the rats with the methanol extract of $T$. conophorum seeds at a dose of 250 and $500 \mathrm{mg} / \mathrm{kg}$ body weight for one week before administering $\mathrm{CCl}_{4}$ showed a

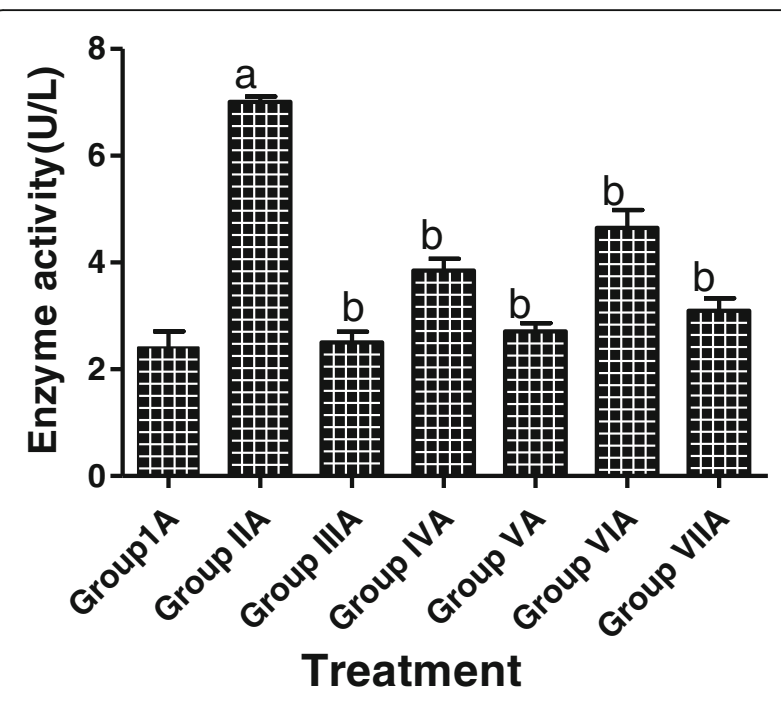

Fig. 2 Effect of methanol extract of T. conophorum seeds on Gamma gtutamyl transferase activities in $\mathrm{CCl}_{4}$ induced hepatotoxicity in rats after $24 \mathrm{~h}$ of intoxication. Values are Mean $\pm \mathrm{SEM}, n=5$ rats in each group. $p<0.05$, a as compared with the normal control group; $b$ as compared with the $\mathrm{CCl}_{4}$ only (group IIA) . $\gamma$-GT - Gamma gtutamyl transferase $\mathrm{CCl}_{4}$, Carbon tetrachloride. Group IA (control) received distilled water and olive oil (i.p), group IIA rats were intoxicated with $\mathrm{CCl}_{4}$ in olive oil (600 mg/kg, i.p.) only on the 8th day, while groups IIIA, IVA and VA were given $100 \mathrm{mg} / \mathrm{kg}$ of silymarin, $250 \mathrm{mg} / \mathrm{kg}$ and $500 \mathrm{mg} / \mathrm{kg}$ of methanol extract, respectively for 7 days, thereafter intoxicated with $\mathrm{CCl}_{4}$ on the 8th day. Groups VIA and VIIA were intoxicated with $\mathrm{CCl}_{4}$ on the 8th day and administered $250 \mathrm{mg} / \mathrm{kg}$ and $500 \mathrm{mg} / \mathrm{kg}$ of methanol extract of T. conophorum seeds at $1 \mathrm{~h}, 6 \mathrm{~h}$, $12 \mathrm{~h}, 18 \mathrm{~h}$ and $24 \mathrm{~h}$. Fasting blood samples were collected after the last administration of the extract at $24 \mathrm{~h}$ of intoxication with $\mathrm{CCl}_{4}$

significant decrease $(p<0.05)$ in $\gamma$-GT and total bilirubin levels when compared to rats administered $\mathrm{CCl}_{4}$ only (Group IIA). The standard drug silymarin at a dose of $100 \mathrm{mg} / \mathrm{kg}$ also significantly prevented the elevation of the $\gamma$-GT and total bilirubin levels. Pre-treatment for a week with the crude methanol extract ( 250 and $500 \mathrm{mg} / \mathrm{kg}$ ) and silymarin exhibited a protection of $45.1 \%, 61.3 \%$ and $64.3 \%$ in $\gamma$-GT activities and $46.8 \%, 75.8 \%$ and $88.7 \%$ in total bilirubin concentrations respectively. Post-treatment of rats with the extract after $\mathrm{CCl}_{4}$ administration at 250 and $500 \mathrm{mg} / \mathrm{kg}$ significantly restored liver damage in a dose-dependent manner.

\section{Effect of methanol extract of $T$. conophorum seeds on antioxidant enzyme activity in $\mathrm{CCl}_{4}$ induced hepatotoxicity in rats after $24 \mathrm{~h}$ of intoxication}

The effect of methanol extract of T. conophorum seeds on antioxidant enzymes in $\mathrm{CCl}_{4}$ induced hepatotoxicity in rats after 24 $\mathrm{h}$ of intoxication is shown in Table 1 . There was a significant $\left(P^{<} 0.05\right)$ decrease in the hepatic enzymatic (CAT, SOD, GPx, and GST) and non-enzymatic (GSH) antioxidants recorded in rats following $\mathrm{CCl}_{4}$ administration. However pre-treatment of the rats with the methanol extract of T. conophorum seeds at a dose of 250 and $500 \mathrm{mg} /$ 


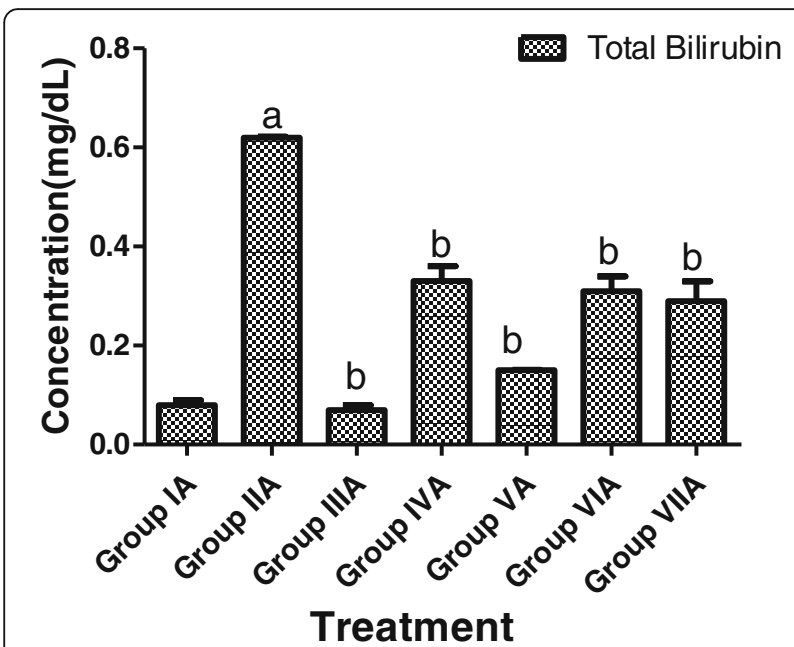

Fig. 3 Effect of methanol extract of T. conophorum seeds on Total bilirubin levels in $\mathrm{CCl}_{4}$ induced hepatotoxicity in rats after $24 \mathrm{~h}$ of intoxication. Values are Mean \pm SEM, $n=5$ rats in each group. $p<0.05$, a as compared with the normal control group; $b$ as compared with the $\mathrm{CCl}_{4}$ only (group IIA). $\mathrm{CCl}_{4}$, Carbon tetrachloride. Group IA (control) received distilled water and olive oil (i.p), group IIA rats were intoxicated with $\mathrm{CCl}_{4}$ in olive oil $(600 \mathrm{mg} / \mathrm{kg}$, i.p.) only on the 8th day, while groups IIIA, IVA and VA were given $100 \mathrm{mg} / \mathrm{kg}$ of silymarin, $250 \mathrm{mg} / \mathrm{kg}$ and $500 \mathrm{mg} / \mathrm{kg}$ of methanol extract, respectively for 7 days, thereafter intoxicated with $\mathrm{CCl}_{4}$ on the 8th day. Groups VIA and VIIA were intoxicated with $\mathrm{CCl}_{4}$ on the 8th day and administered $250 \mathrm{mg} /$ $\mathrm{kg}$ and $500 \mathrm{mg} / \mathrm{kg}$ of methanol extract of T. conophorum seeds at $1 \mathrm{~h}$, $6 \mathrm{~h}, 12 \mathrm{~h}, 18 \mathrm{~h}$ and $24 \mathrm{~h}$. Fasting blood samples were collected after the last administration of the extract at $24 \mathrm{~h}$ of intoxication with $\mathrm{CCl}_{4}$

$\mathrm{kg}$ body weight for one week before administration of $\mathrm{CCl}_{4}$ showed significant increases $\left(p^{<} 0.001 ; p<0.05\right)$ in CAT, SOD, GSH and GPx, activities in a dose-dependent manner compared to rats intoxicated with $\mathrm{CCl}_{4}$ only (group IIA), while non-significant increase in GST activities were observed at the two different doses when compared to group IIA. The standard drug silymarin at a dose of $100 \mathrm{mg} / \mathrm{kg}$ also significantly increased the antioxidant status in rats in group IIIA. However, post-treatment of the rats in groups VIA and VIIA with the extract at a dose of 250 and $500 \mathrm{mg} / \mathrm{kg}$ showed significant increases in CAT and GSH activities in a dose-dependent manner. There was no significant difference in SOD and GPx activities in rats administered with $250 \mathrm{mg} / \mathrm{kg}$ of extract (group VIA) but significantly increased $(p<0.05)$ when given $500 \mathrm{mg} / \mathrm{kg}$ of the extract (group VIIA).

\section{Effect of methanol extract of $T$. conophorum seeds on liver lipid peroxidation in $\mathrm{CCl}_{4}$ induced hepatotoxicity in rats after $24 \mathrm{~h}$ of intoxication}

The effect of methanol extract of T. conophorum seeds on lipid peroxidation levels in $\mathrm{CCl}_{4}$ induced hepatotoxicity in rats after $24 \mathrm{~h}$ of intoxication is shown in Fig. 4. Hepatic MDA level was remarkably increased by $55.1 \%\left(p^{<} 0.05\right)$ in $\mathrm{CCl}_{4}$ treated group as compared to control group, $24 \mathrm{~h}$ after $\mathrm{CCl}_{4}$ administration. Pre-treatment with the extract at different doses (250 and $500 \mathrm{mg} / \mathrm{kg}$ ) significantly decreased hepatic MDA levels. MDA levels were decreased by $58.6 \%$, $22.9 \%$ and $52.1 \%$ in groups IIIA, IVA and VA respectively, compared to $\mathrm{CCl}_{4}$ treated group (group IIA), while post-treatment of the rats in groups VIA and VIIA with the extract at a dose of 250 and $500 \mathrm{mg} / \mathrm{kg}$ showed significant decrease in MDA levels in a dose-dependent manner.

\section{Effect of methanol extract of $T$. conophorum seeds on} serum aspartate aminotransferase, alanine aminotransferase and alkaline phosphatase in $\mathrm{CCl}_{4}$ induced hepatotoxicity in rats after $48 \mathrm{~h}$ of intoxication The effect of methanol extract of T. conophorum seeds on serum biochemical parameters (AST, ALT, ALP) in $\mathrm{CCl}_{4}$ induced hepatotoxicity in rats after $48 \mathrm{~h}$ of intoxication is shown in Fig. 5. Administration of $\mathrm{CCl}_{4}$ at a dose of $600 \mathrm{mg} / \mathrm{kg}$ body weight significantly increased ( $\mathrm{p}<0.05$ )

Table 1 Effect of methanol extract of $T$. conophorum seeds on liver antioxidant status in $\mathrm{CCl}_{4}$ induced hepatotoxicity in rats after $24 \mathrm{~h}$ of intoxication

\begin{tabular}{|c|c|c|c|c|c|}
\hline \multirow{2}{*}{$\begin{array}{l}\text { Treatment } \\
(n=5)\end{array}$} & \multicolumn{5}{|l|}{ Parameters } \\
\hline & CAT (Unit/mg protein) & SOD (Unit/mg protein) & GPx (Unit/mg protein) & GST (Unit/mg protein & $\mathrm{GSH}(\mu \mathrm{g} / \mathrm{mg}$ protein \\
\hline Group1A & $32.20 \pm 1.20$ & $6.00 \pm 0.50$ & $4.20 \pm 0.22$ & $0.53 \pm 0.03$ & $14.50 \pm 0.25$ \\
\hline Group IIA & $* * * 16.42 \pm 1.12^{\mathrm{a}}$ & $* * * 2.55 \pm 0.08^{\mathrm{a}}$ & $* * * 2.69 \pm 0.10^{a}$ & $* * 0.30 \pm 0.05^{\mathrm{a}}$ & $* * * 6.41 \pm 0.15$ \\
\hline Group IIIA & $* * * 30.25 \pm 0.50^{b}$ & $* * * 5.50 \pm 0.15^{b}$ & $* * * 4.12 \pm 0.11^{b}$ & ${ }^{*} 0.50 \pm 0.05^{b}$ & $* * * 18.20 \pm 0.45$ \\
\hline Group IVA & $* * * 25.50 \pm 0.55^{b}$ & $* 3.50 \pm 0.05^{b}$ & $* * 3.46 \pm 0.05^{b}$ & $0.35 \pm 0.01^{\mathrm{a}}$ & $* * * 15.20 \pm 0.40$ \\
\hline Group VA & $* * * 28.00 \pm 0.40^{b}$ & $* * * 5.06 \pm 0.20^{b}$ & $* * 3.43 \pm 0.02^{b}$ & ${ }^{*} 0.45 \pm 0.05^{b}$ & $* * * 15.00 \pm 0.06$ \\
\hline GroupVIA & $* * * 23.30 \pm 0.30^{b}$ & $2.80 \pm 0.08^{b}$ & $3.13 \pm 0.04^{b}$ & $0.32 \pm 0.03^{b}$ & $* * * 15.70 \pm 0.16$ \\
\hline GroupVIIA & $* * * 27.62 \pm 0.60^{b}$ & $* * 4.00 \pm 0.12^{b}$ & $* * * 3.54 \pm 0.09^{b}$ & $0.40 \pm 0.01^{a}$ & $* * * 16.20 \pm 0.20$ \\
\hline
\end{tabular}

Values are Mean $\pm \mathrm{SEM}, \mathrm{n}=5$ rats in each group, ${ }^{*} \mathrm{P}^{<} 0.05 ;{ }^{* *} p<0.01 ;{ }^{* * *} p<0.001$, a as compared with the normal saline (control) group; $\mathrm{b}$ as compared with the $\mathrm{CCl}_{4}$ only group SOD Superoxide dismutase; CAT Catalase; GPX Glutathione peroxidase; GST Glutathione-S-Transferase Group IA (control) received distilled water and olive oil (i.p), group IIA rats were intoxicated with $\mathrm{CCl}_{4}$ in olive oil (600 mg/kg, i.p.) only on the 8 th day, while groups IIIA, IVA and VA were given $100 \mathrm{mg} / \mathrm{kg}$ of silymarin, $250 \mathrm{mg} / \mathrm{kg}$ and $500 \mathrm{mg} / \mathrm{kg}$ of methanol extract respectively for 7 days, thereafter intoxicated with CCl on the 8th day. Groups VIA and VIIA were intoxicated with $\mathrm{CCl}_{4}$ on the 8th day and administered $250 \mathrm{mg} / \mathrm{kg}$ and $500 \mathrm{mg} / \mathrm{kg}$ of methanol extract of $T$. conophorum seeds at $1 \mathrm{~h}, 6 \mathrm{~h}, 12 \mathrm{~h}, 18 \mathrm{~h}$ and $24 \mathrm{~h}$. Fasting blood samples were collected after the last administration of the extract at $24 \mathrm{~h}$ of intoxication with $\mathrm{CCl}_{4}$ 


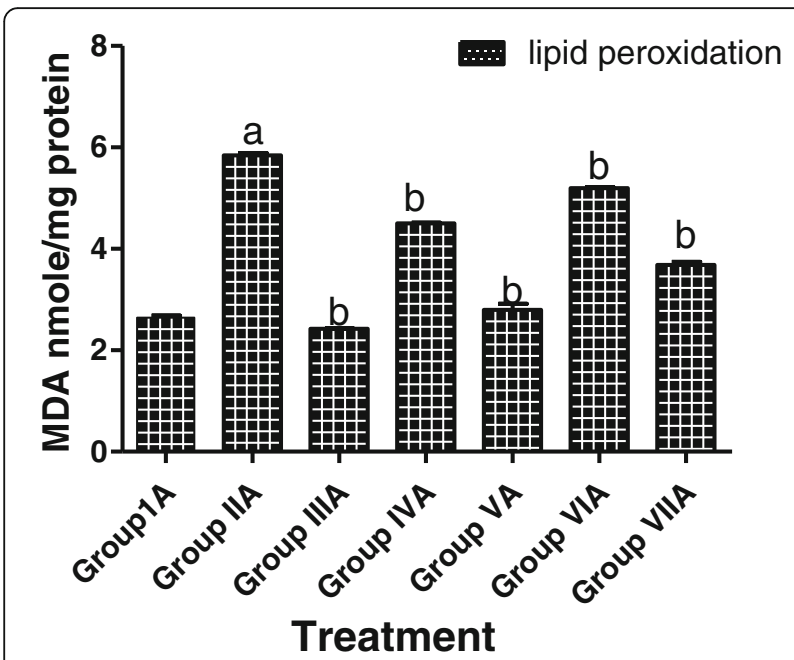

Fig. 4 Effect of methanol extract of T. conophorum seeds on lipid peroxidation levels in $\mathrm{CCl}_{4}$ induced hepatotoxicity in rats after $24 \mathrm{~h}$ of intoxication. Values are Mean $\pm \mathrm{SEM}, n=5$ rats in each group. $p<$ 0.05 , a as compared with the normal control group; $b$ as compared with the $\mathrm{CCl}_{4}$ only (group IIA). $\mathrm{CCl}_{4}$, Carbon tetrachloride, MDAmalondialdehyde. Group IA (control) received distilled water and olive oil (i.p), group IIA rats were intoxicated with $\mathrm{CCl}_{4}$ in olive oil (600 mg/kg, i.p.) only on the 8th day, while groups IIIA, IVA and VA were given $100 \mathrm{mg} / \mathrm{kg}$ of silymarin, $250 \mathrm{mg} / \mathrm{kg}$ and $500 \mathrm{mg} / \mathrm{kg}$ of methanol extract, respectively for 7 days, thereafter intoxicated with $\mathrm{CCl}_{4}$ on the 8th day. Groups VIA and VIIA were intoxicated with $\mathrm{CCl}_{4}$ on the 8th day and administered $250 \mathrm{mg} / \mathrm{kg}$ and $500 \mathrm{mg} / \mathrm{kg}$ of methanol extract of $T$. conophorum seeds at $1 \mathrm{~h}, 6 \mathrm{~h}, 12 \mathrm{~h}, 18 \mathrm{~h}$ and $24 \mathrm{~h}$. Fasting blood samples were collected after the last administration of the extract at $24 \mathrm{~h}$ of intoxication with $\mathrm{CCl}_{4}$

the activities of the serum enzymes, AST ALT, ALP by $69.6 \%, 62.5 \%$, and $64.7 \%$ respectively after $48 \mathrm{~h}$ of intoxication when compared with the control. Pre-treatment of the rats with the methanol extract of $T$. conophorum seeds at a dose of 250 and $500 \mathrm{mg} / \mathrm{kg}$ body weight for one week before the administration of $\mathrm{CCl}_{4}$ showed a significant decrease ( $\left.\mathrm{p}^{<} 0.05\right)$ in AST, ALT and ALP. The standard drug silymarin at a dose of $100 \mathrm{mg} / \mathrm{kg}$ also significantly prevented the elevation of serum enzymes. Pre-treatment with crude methanol extract ( 250 and $500 \mathrm{mg} / \mathrm{kg}$ ) and silymarin exhibited a protection of $16.7 \%, 55 \%$ and $68.1 \%$ in AST levels, $25 \%, 70.8 \%$ and $75 \%$ in ALT levels, $43.3 \%, 73.4 \%$ and $62.4 \%$ in ALP levels respectively. Post-treatment of rats with the methanol extract after $\mathrm{CCl}_{4}$ administration at 250 and $500 \mathrm{mg} / \mathrm{kg}$ significantly restored liver damage in a dose dependent manner.

Effect of methanol extract of $T$. conophorum seeds on gamma gtutamyl transferase and Total bilirubin levels in $\mathrm{CCl}_{4}$ induced hepatotoxicity in rats after $48 \mathrm{~h}$ of intoxication The effect of methanol extract of T. conophorum seeds on serum $\gamma$-GT and total bilirubin levels in $\mathrm{CCl}_{4}$ induced hepatotoxicity in rats after $48 \mathrm{~h}$ of intoxication is shown in Figs. 6 and 7 respectively. Administration of $\mathrm{CCl}_{4}$ at a

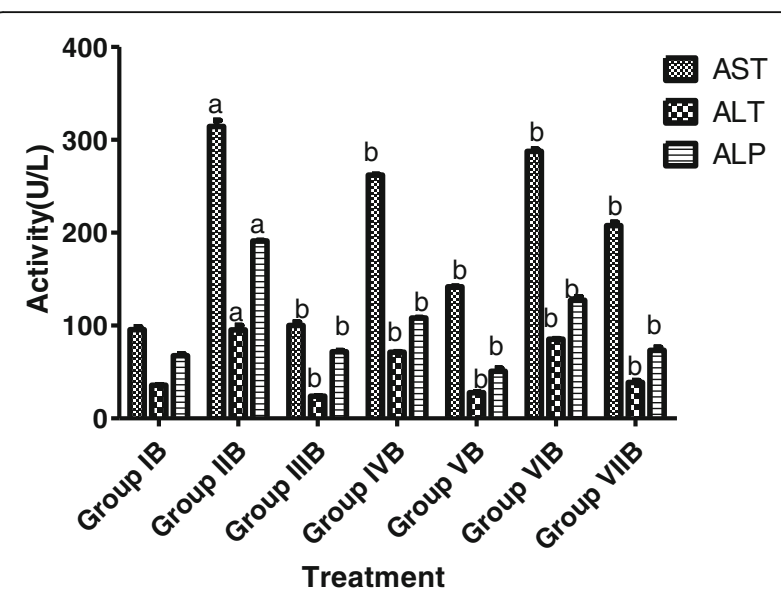

Fig. 5 Effect of methanol extract of T. conophorum seeds on serum Aspartate aminotransferase, Alanine aminotransferase and Alkaline phosphatase activities in $\mathrm{CCl}_{4}$ induced hepatotoxicity in rats after $48 \mathrm{~h}$ of intoxication. Values are Mean $\pm \mathrm{SEM}, n=5$ rats in each group. $p<0.05$, a as compared with the normal control group; b as compared with the $\mathrm{CCl}_{4}$ only (group IIB). AST- Aspartate aminotransferase; ALT- Alanine aminotransferase; ALP - Alkaline phosphatase; $\mathrm{CCl}_{4}$ - Carbon tetrachloride. Group IB (control) received distilled water and olive oil (i.p), group IIB rats were intoxicated with $\mathrm{CCl}_{4}$ in olive oil $(600 \mathrm{mg} / \mathrm{kg}$, i.p.) only on the 8 th day, while groups IIIB, IVB and VB were given $100 \mathrm{mg} / \mathrm{kg}$ of silymarin, $250 \mathrm{mg} / \mathrm{kg}$ and $500 \mathrm{mg} / \mathrm{kg}$ of methanol extract respectively for 7 days, thereafter intoxicated with $\mathrm{CCl}_{4}$ on the 8th day. Groups VIB and VIIB were intoxicated with $\mathrm{CCl}_{4}$ on the 8th day and administered $250 \mathrm{mg} / \mathrm{kg}$ and $500 \mathrm{mg} / \mathrm{kg}$ of methanol extract of $T$. conophorum seeds at $1 \mathrm{~h}$, $6 \mathrm{~h}, 12 \mathrm{~h}, 18 \mathrm{~h}$ and $24 \mathrm{~h}$. Fasting blood samples were collected after the last administration of the extract at $48 \mathrm{~h}$ of intoxication with $\mathrm{CCl}_{4}$

dose of $600 \mathrm{mg} / \mathrm{kg}$ body weight significantly increased ( $\mathrm{p}^{\text {< }}$ 0.05 ) the levels of the serum $\gamma$-GT and total bilirubin by $70.6 \%$ and $87.5 \%$ respectively when compared with the normal control (Group IB). Pre-treatment of the rats with the methanol extract of $T$. conophorum seeds at a dose of 250 and $500 \mathrm{mg} / \mathrm{kg}$ body weight for one week before administering $\mathrm{CCl}_{4}$ showed a significant decrease $(p<0.05)$ in $\gamma$-GT and total bilirubin levels when compared to rats administered $\mathrm{CCl}_{4}$ only (Group IIB). The standard drug silymarin at a dose of $100 \mathrm{mg} / \mathrm{kg}$ also significantly prevented the elevation of the $\gamma$-GT and total bilirubin. Pre-treatment for a week with the crude methanol extract (250 and $500 \mathrm{mg} / \mathrm{kg}$ ) and silymarin exhibited a protection of $49 \%, 64.1 \%$ and $70.2 \%$ in $\gamma$-GT activities and $62.5 \%$, $70.8 \%$ and $80.6 \%$ in total bilirubin concentrations respectively. Post-treatment of rats with the extract after $\mathrm{CCl}_{4}$ administration at 250 and $500 \mathrm{mg} / \mathrm{kg}$ significantly restored liver damage in a dose-dependent manner.

Effect of methanol extract of $T$. conophorum seeds on antioxidant enzyme activities in $\mathrm{CCl}_{4}$ induced hepatotoxicity in rats after $48 \mathrm{~h}$ of intoxication The effect of methanol extract of $T$. conophorum seeds on antioxidant enzymes and lipid peroxidation in $\mathrm{CCl}_{4}$ 


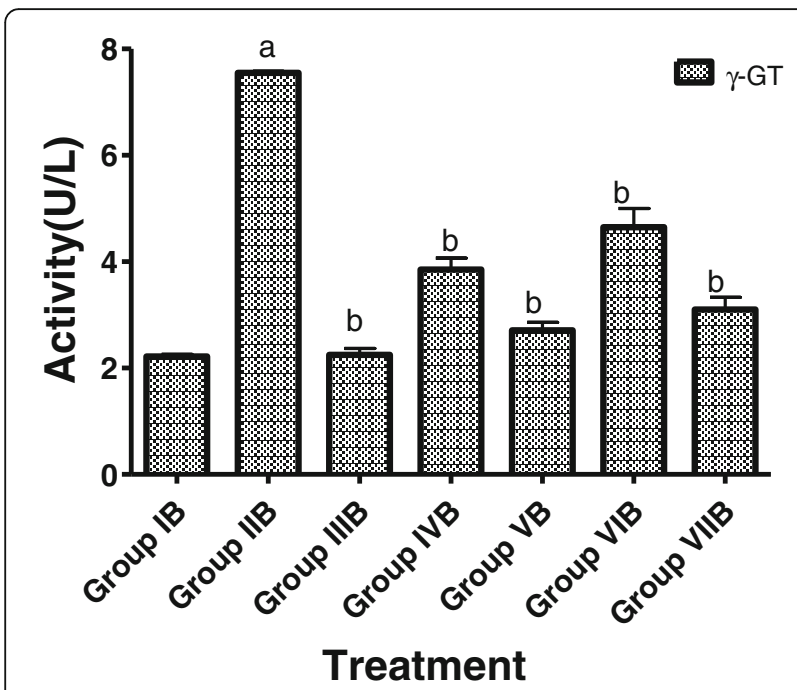

Fig. 6 Effect of methanol extract of T. conophorum seeds on Gamma gtutamyl transferase activities in $\mathrm{CCl}_{4}$ induced hepatotoxicity in rats after $48 \mathrm{~h}$ of intoxication. Values are Mean \pm SEM, $n=5$ rats in each group. $p<0.05$, a as compared with the normal control group; b as compared with the $\mathrm{CCl}_{4}$ only (group IIB). Y-GT - Gamma gtutamyl transferase $\mathrm{CCl}_{4}$ - Carbon tetrachloride. Group IB (control) received distilled water and olive oil (i.p), group IIB rats were intoxicated with $\mathrm{CCl}_{4}$ in olive oil $(600 \mathrm{mg} / \mathrm{kg}$, i.p.) only on the 8th day, while groups IIIB, IVB and VB were given $100 \mathrm{mg} / \mathrm{kg}$ of silymarin, $250 \mathrm{mg} / \mathrm{kg}$ and $500 \mathrm{mg} / \mathrm{kg}$ of methanol extract, respectively for 7 days, thereafter intoxicated with $\mathrm{CCl}_{4}$ on the 8th day. Groups VIB and VIIB were intoxicated with $\mathrm{CCl}_{4}$ on the 8th day and administered $250 \mathrm{mg} / \mathrm{kg}$ and $500 \mathrm{mg} / \mathrm{kg}$ of methanol extract of T. conophorum seeds at 1 h, 6 h, 12 h, 18 h and 24 h. Fasting blood samples were collected after the last administration of the extract at $48 \mathrm{~h}$ of intoxication with $\mathrm{CCl}_{4}$

induced hepatotoxicity in rats after $48 \mathrm{~h}$ of intoxication is shown in Table 2. There was a significant $(p<0.05)$ decrease in the hepatic enzymatic (CAT, SOD, GPx, and GST) and non-enzymatic (GSH) antioxidants recorded in rats following $\mathrm{CCl}_{4}$ administration. However pre-treatment of the rats with the methanol extract of $T$. conophorum seeds at doses of 250 and $500 \mathrm{mg} / \mathrm{kg}$ body weight for 7 days before the administration of $\mathrm{CCl}_{4}$ showed significant increases $\left(p^{<} 0.001\right.$; $P<0.05)$ in CAT, SOD, GSH and GPx, activities in a dose-dependent manner compared to rats intoxicated with $\mathrm{CCl}_{4}$ only (group IIB), while non-significant increase in GST activities was observed at $250 \mathrm{mg} / \mathrm{kg}$ extract dose (group IVB) when compared to group IIB, but there was a significant increase $\left(p^{<} 0.05\right)$ when given $500 \mathrm{mg} / \mathrm{kg}$ dose of the extract to group VB. Standard drug silymarin at a dose of $100 \mathrm{mg} / \mathrm{kg}$ also attenuated the toxic effect of $\mathrm{CCl}_{4}$ in group IIIB rats. However, post-treatment of the rats in groups VIB and VIIB with the extract at a dose of $500 \mathrm{mg} / \mathrm{kg}$ showed significant increases in CAT, SOD, GPx, GST activities and GSH levels in a dose-dependent manner. There was no significant difference in CAT, SOD and GPx activities in rats administered with $250 \mathrm{mg} / \mathrm{kg}$ of the extract (group VIB).

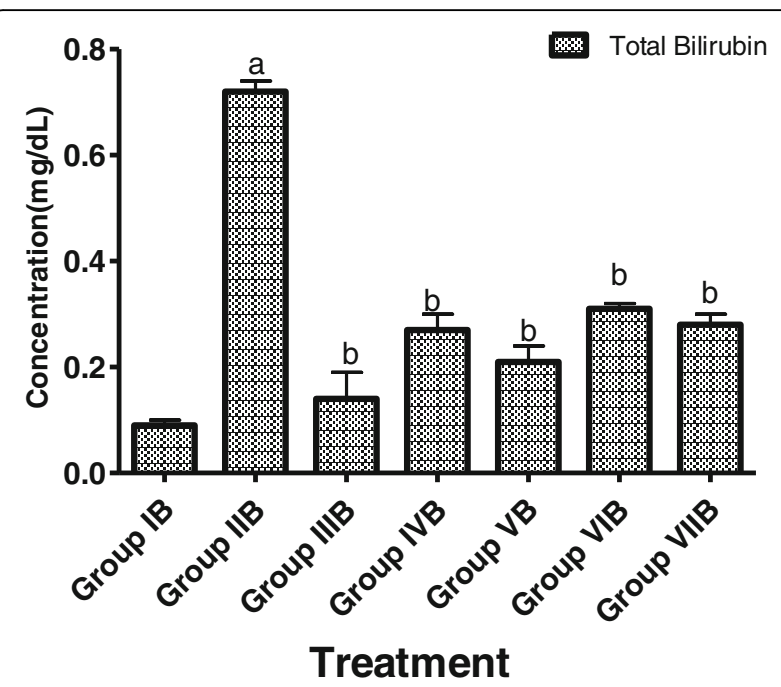

Fig. 7 Effect of methanol extract of $T$. conophorum seeds on Total bilirubin in $\mathrm{CCl}_{4}$ induced hepatotoxicity in rats after $48 \mathrm{~h}$ of intoxication. Values are Mean \pm SEM, $n=5$ rats in each group. $p<$ 0.05, a as compared with the normal control group; b as compared with the $\mathrm{CCl}_{4}$ only(group IIB), $\mathrm{CCl}_{4}$, Carbon tetrachloride. Group IB (control) received distilled water and olive oil (i.p), group IIB rats were intoxicated with $\mathrm{CCl}_{4}$ in olive oil $(600 \mathrm{mg} / \mathrm{kg}$, i.p.) only on the 8th day, while groups IIIB, IVB and VB were given $100 \mathrm{mg} / \mathrm{kg}$ of silymarin, $250 \mathrm{mg} / \mathrm{kg}$ and $500 \mathrm{mg} / \mathrm{kg}$ of methanol extract, respectively for 7 days, thereafter intoxicated with $\mathrm{CCl}_{4}$ on the 8th day. Groups VIB and VIIB were intoxicated with $\mathrm{CCl}_{4}$ on the 8th day and administered $250 \mathrm{mg} / \mathrm{kg}$ and $500 \mathrm{mg} / \mathrm{kg}$ of methanol extract of T. conophorum seeds at $1 \mathrm{~h}, 6 \mathrm{~h}, 12 \mathrm{~h}, 18 \mathrm{~h}$ and $24 \mathrm{~h}$. Fasting blood samples were collected after the last administration of the extract at $48 \mathrm{~h}$ of intoxication with $\mathrm{CCl}_{4}$

Effect of methanol extract of $T$. conophorum seeds on liver lipid peroxidation in $\mathrm{CCl}_{4}$ induced hepatotoxicity in rats after $48 \mathrm{~h}$ of intoxication

The effect of methanol extract of $T$. conophorum seeds on lipid peroxidation levels in $\mathrm{CCl}_{4}$ induced hepatotoxicity in rats after $48 \mathrm{~h}$ of intoxication is shown in Fig. 8. Hepatic MDA level was remarkably increased by $79.5 \%$ $(p<0.05)$ in $\mathrm{CCl}_{4}$ treated group only compared to control group, after $48 \mathrm{~h}$ of intoxication. Pre-treatment with the extract before administration of $\mathrm{CCl}_{4}$ at different doses $(250$ and $500 \mathrm{mg} / \mathrm{kg}$ ) significantly decreased hepatic MDA levels. MDA levels were decreased by $80.8 \%, 46.2 \%$ and $71.8 \%$ in groups IIIB, IVB and VB respectively, compared to $\mathrm{CCl}_{4}$ treated group (group IIB), while post-treatment of the rats in groups VIB and VIIB with the extract at a dose of 250 and $500 \mathrm{mg} / \mathrm{kg}$ showed significant decrease in MDA levels in a dose-dependent manner.

\section{Histopathological examination of the liver}

Histopathological examination of the liver of normal control rats and rats intoxicated with $\mathrm{CCl}_{4}$ after $24 \mathrm{~h}$ and $48 \mathrm{~h}$ intoxication is shown in Figs. 9 and 10 respectively. Figures 9 and 10 are sections of the liver from a 
Table 2 Effect of methanol extract of T. conophorum seeds on Liver Antioxidant Status in $\mathrm{CCl}_{4}$ induced hepatotoxicity in rats after $48 \mathrm{~h}$ of intoxication

\begin{tabular}{|c|c|c|c|c|c|}
\hline \multirow{2}{*}{$\begin{array}{l}\text { Treatment } \\
(n=5)\end{array}$} & \multicolumn{5}{|l|}{ Parameters } \\
\hline & Catalase (Unit/mg protein) & SOD (Unit/mg protein) & GPx (Unit/mg protein) & GST (Unit/mg protein & GSH ( $\mu \mathrm{g} / \mathrm{mg}$ protein) \\
\hline Group1B:Normal control & $70.20 \pm 3.50$ & $6.70 \pm 0.53$ & $3.80 \pm 0.16$ & $0.62 \pm 0.02$ & $16.80 \pm 0.53$ \\
\hline Group ॥B & $* * * 44.50 \pm 1.20^{\mathrm{a}}$ & $* * * 2.50 \pm 0.50^{a}$ & $* * 1.50 \pm 0.06^{a}$ & $* * * 0.29 \pm 0.001^{a}$ & $* * * 7.01 \pm 0.50^{\mathrm{a}}$ \\
\hline Group IIIB & $* * * 70.50 \pm 2.50^{b}$ & $* * * 6.50 \pm 0.25^{b}$ & $* * * 4.40 \pm 0.15^{b}$ & $* * 0.51 \pm 0.06^{b}$ & $* * * 17.02 \pm 0.25^{b}$ \\
\hline Group IVB & $50.00 \pm 1.17^{b}$ & $* 4.20 \pm 0.20^{b}$ & $* * * 3.46 \pm 0.10^{b}$ & $0.26 \pm 0.01^{a}$ & $* * * 10.20 \pm 0.15^{b}$ \\
\hline Group VB & $* * * 66.90 \pm 2.00^{b}$ & $* * 6.05 \pm 0.15^{b}$ & $* * * 3.43 \pm 0.21^{b}$ & ${ }^{* *} 0.43 \pm 0.001^{b}$ & $* * * 15.20 \pm 0.40^{b}$ \\
\hline Group VIB & $48.50 \pm 3.80^{b}$ & $2.62 \pm 0.60^{b}$ & $* * 2.69 \pm 0.07^{b}$ & $0.30 \pm 0.003^{b}$ & $* * * 11.80 \pm 0.30^{b}$ \\
\hline Group VIIB & $* * * 68.00 \pm 2.55^{b}$ & $* * * 5.50 \pm 0.11^{b}$ & $* * 3.12 \pm 0.20$ & $* * 0.45 \pm 0.02^{b}$ & $* * * 14.00 \pm 0.28^{b}$ \\
\hline
\end{tabular}

Values are Mean $\pm \mathrm{SD}, n=4$ rats in each group. ${ }^{*} \mathrm{P}^{<} 0.05$; ${ }^{* *} p<0.01$; ${ }^{* *} p<0.001$, a as compared with the normal saline (control) group; $\mathrm{b}$ as compared with the $\mathrm{CCl}_{4}$ only group SOD Superoxide dismutase; CAT Catalase; GSH Reduced glutathione; GPx Glutathione peroxidase; GST Glutathione-S-Transferase,CCl Carbon tetrachloride

Group IB (control) received distilled water and olive oil (i.p), group IIB rats were intoxicated with $\mathrm{CCl}_{4}$ in olive oil (600 mg/kg, i.p.) only on the 8 th day, while groups IIIB, IVB and VB were given $100 \mathrm{mg} / \mathrm{kg}$ of silymarin, $250 \mathrm{mg} / \mathrm{kg}$ and $500 \mathrm{mg} / \mathrm{kg}$ of methanol extract respectively for 7 days, thereafter intoxicated with $\mathrm{CCl}_{4}$ on the 8th day. Groups VIB and VIIB were intoxicated with $\mathrm{CCl}_{4}$ on the 8th day and administered $250 \mathrm{mg} / \mathrm{kg}$ and $500 \mathrm{mg} / \mathrm{kg}$ of methanol extract of $T$. conophorum seeds at $1 \mathrm{~h}, 6 \mathrm{~h}, 12 \mathrm{~h}, 18 \mathrm{~h}$ and 24 h.Fasting blood samples were collected after the last administration of the extract at $48 \mathrm{~h}$ of intoxication with $\mathrm{CCl}_{4}$

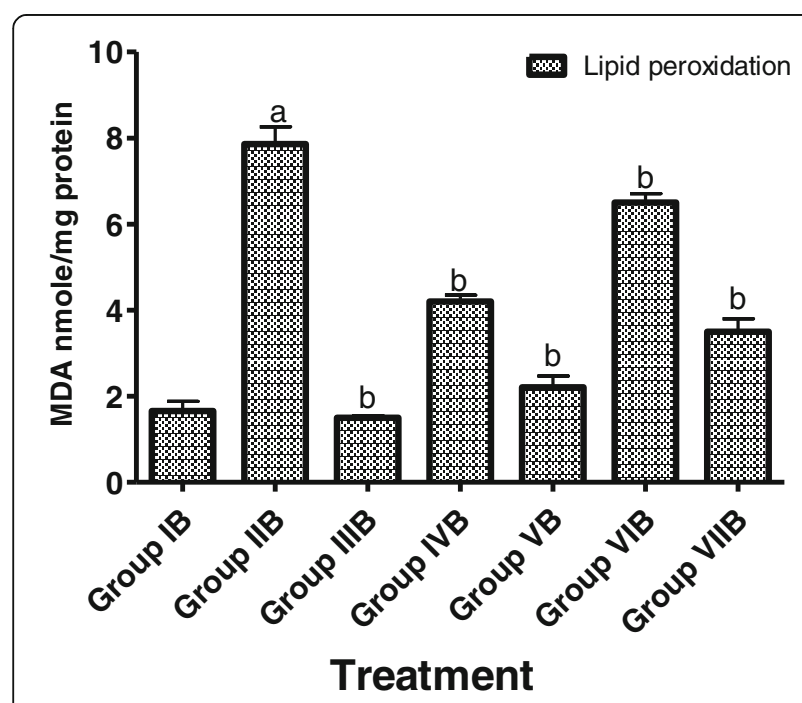

Fig. 8 Effect of methanol extract of T. conophorum seeds on lipid peroxidation levels in $\mathrm{CCl}_{4}$ induced hepatotoxicity in rats after $48 \mathrm{~h}$ of intoxication. Values are Mean \pm SEM, $n=5$ rats in each group. $p<$ 0.05 , a as compared with the normal control group; $b$ as compared with the $\mathrm{CCl}_{4}$ only (group IIB), $\mathrm{CCl}_{4}$, Carbon tetrachloride, MDAmalondialdehyde. Group IB (control) received distilled water and olive oil (i.p), group IIB rats were intoxicated with $\mathrm{CCl}_{4}$ in olive oil ( $600 \mathrm{mg} / \mathrm{kg}$, i.p.) only on the 8th day, while groups IIIB, IVB and VB were given $100 \mathrm{mg} / \mathrm{kg}$ of silymarin, $250 \mathrm{mg} / \mathrm{kg}$ and $500 \mathrm{mg} / \mathrm{kg}$ of methanol extract, respectively for 7 days, thereafter intoxicated with $\mathrm{CCl}_{4}$ on the 8th day. Groups VIB and VIIB were intoxicated with $\mathrm{CCl}_{4}$ on the 8th day and administered $250 \mathrm{mg} / \mathrm{kg}$ and $500 \mathrm{mg} / \mathrm{kg}$ of methanol extract of $T$. conophorum seeds at $1 \mathrm{~h}, 6 \mathrm{~h}, 12 \mathrm{~h}, 18 \mathrm{~h}$ and $24 \mathrm{~h}$. Fasting blood samples were collected after the last administration of the extract at $48 \mathrm{~h}$ of intoxication with $\mathrm{CCl}_{4}$ representative rat in each of the five groups. Figures 9 and 10 , show that under the conditions of this experiment, carbon tetrachloride caused damage to the liver mainly by inducing macrovesicular steatosis, congestion of the centriole and extensive hemorrhagic necrosis. The plant extract was able to ameliorate the harmful effects of carbon tetrachloride to varying degrees; with the highest dose seeming most effective. The results observed in this study supported the biochemical results.

\section{Discussion}

Carbon tetrachloride induced hepatotoxicity in rats is a well characterized experimental model for evaluating the hepatoprotective potential of various herbal extract/natural compounds [33, 34]. Hepatic cytochrome P450 metabolizes $\mathrm{CCl}_{4}$ and forms the trichloromethyl free radical $\left(\mathrm{CCl}_{3}{ }^{-}\right)$. This $\mathrm{CCl}_{3}{ }^{-}$radical forms a more toxic trichloromethyl peroxyl radical $\left(\mathrm{CCl}_{3} \mathrm{O}_{2}\right)$ in the presence of oxygen. It is capable of abstracting hydrogen from polyunsaturated fatty acids of the cell membrane to initiate lipid peroxidation and formation of oxidation products such as malondialdehyde and 4-hydroxynonenal [35]. As a result, plasma membrane becomes more permeable to $\mathrm{Ca}^{2+}$ leading to perturbations in calcium homeostasis that culminates in necrotic cell death [36].

The current study showed that treatment with $\mathrm{CCl}_{4}$ at a dose of $600 \mathrm{mg} / \mathrm{kg}$ after 24 and $48 \mathrm{~h}$ of intoxication respectively led to the development of hepatic injury in rats. Serum activities of AST, ALT, ALP, $\gamma$-GT and total bilirubin level were significantly increased $\left(\mathrm{P}^{<} 0.05\right)$ in the rats treated with CCl4 only when compared with the rats in the control groups (Figs. 1, 2 and 3). These serum enzymes according to Zimmerman [37] have been identified to be increased in cytotoxic and cholestatic hepatic injuries. Elevation of AST has been reported to be an 


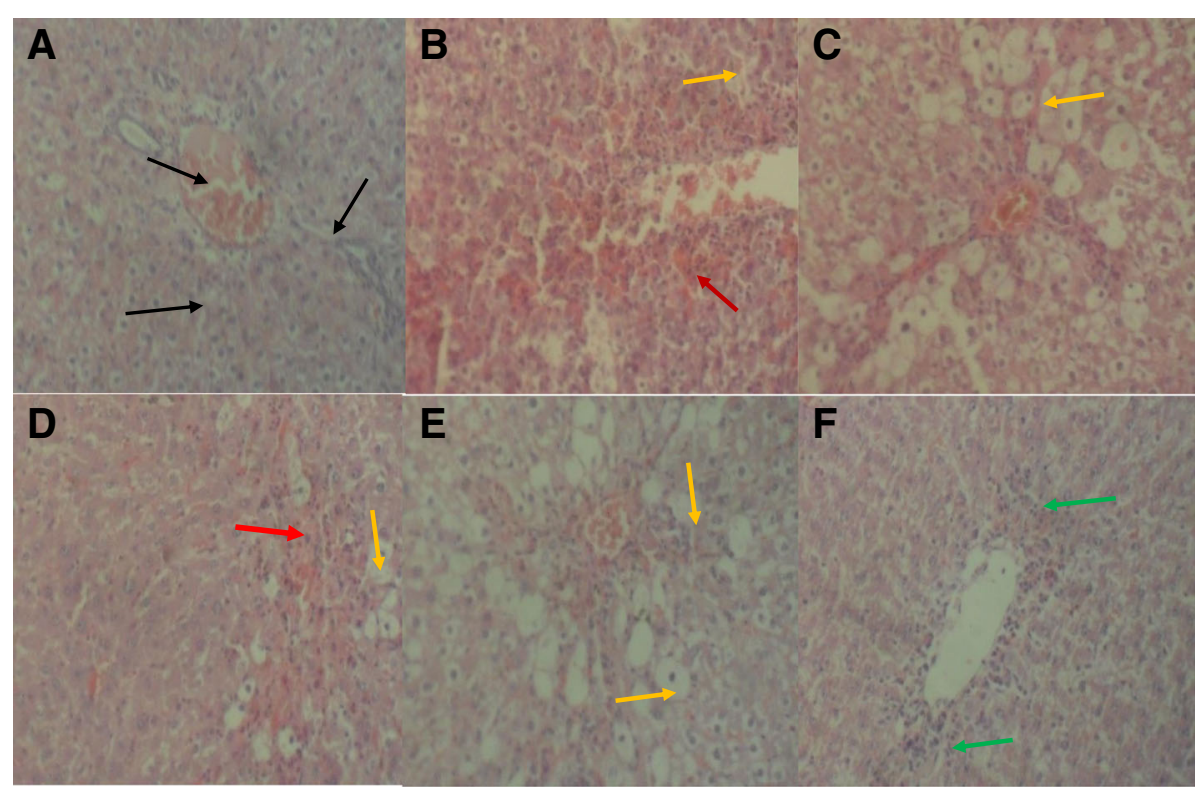

Fig. 9 Photomicrographs of liver sectionsfrom a Control rats showing normal liver histology: Black arrow heads indicatenormal portal vein and hepatocytes with well fenestrated sinusoidal space, $\mathbf{b}$ rats intoxicated with $\mathrm{CCl}_{4}$ on the 8th day $\mathbf{c}$ rats treated with $250 \mathrm{mg} / \mathrm{kg}$ bw.TC seed for 7 days,thereafter intoxicated with $\mathrm{CCl}_{4}$ on the 8 th day $\mathbf{d}$ rats treated with $500 \mathrm{mg} / \mathrm{kg} \mathrm{bw}$.TC seed for 7 days,thereafter intoxicated with $\mathrm{CCl}_{4}$ on the 8th day e rats intoxicated with $\mathrm{CCl}_{4}$ and then given methanol extract of TCseed ( $250 \mathrm{mg} / \mathrm{kg}$ body weight orally) at $1 \mathrm{~h}, 6 \mathrm{~h}, 12 \mathrm{~h}, 18 \mathrm{~h}$ and $24 \mathrm{~h} \mathbf{f}$ rats intoxicated with $\mathrm{CCl}_{4}$ and then given methanol extract of TCseed (500 mg/kg body weight orally) at $1 \mathrm{~h}, 6 \mathrm{~h}, 12 \mathrm{~h}, 18 \mathrm{~h}$ and $24 \mathrm{~h}$. The liver sections were stained with H/E and observed with a 10X objective. Arrow heads (Orange): Vesicular steatosis/fatty accumulation; (Dark Red): Extensive hemorrhagic necrosis; (Light Red): Mild hemorrhagic necrosis; (Green): Mild portal hepatitis. TC: Tetracarpidium conophorum

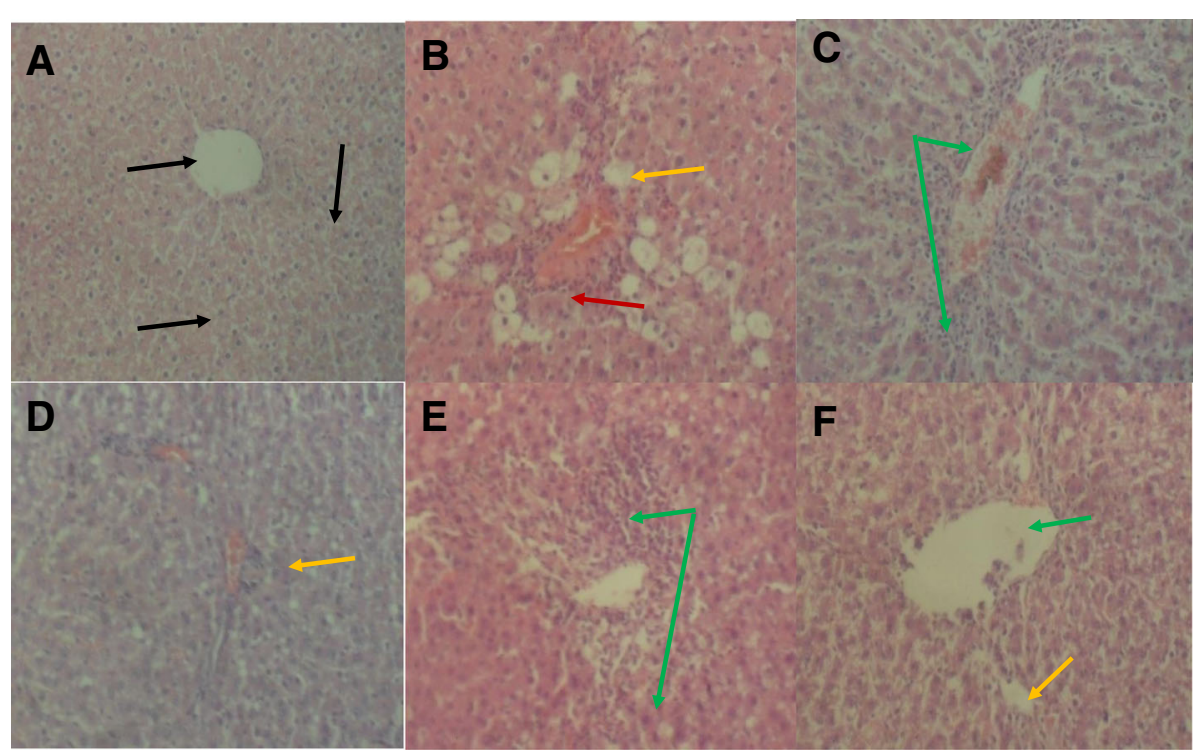

Fig. 10 Photomicrographs of liver sections from a Control rats showing normal liver histology: Black arrow heads indicate normal central vein, hepatocytes, sinusoids $\mathbf{b}$ rats intoxicated with $\mathrm{CCl}_{4}$ on the 8 th day $\mathbf{c}$ rats treated with $250 \mathrm{mg} / \mathrm{kg} \mathrm{bw.TC}$ for 7 days, thereafter intoxicated with $\mathrm{CCl}_{4}$ on the 8th day $\mathbf{d}$ rats treated with $500 \mathrm{mg} / \mathrm{kg}$ bw.TC seed for 7 days,thereafter intoxicated with $\mathrm{CCl}_{4}$ on the 8th day e rats intoxicated with $\mathrm{CCl}_{4}$ and then given methanol extract of TC seed ( $250 \mathrm{mg} / \mathrm{kg}$ body weight orally) at $1 \mathrm{~h}, 6 \mathrm{~h}, 12 \mathrm{~h}, 18 \mathrm{~h}$ and $24 \mathrm{~h} \mathbf{f}$ rats intoxicated with CCl and then given methanol extract of TC seed (500 mg/kg body weight orally) at $1 \mathrm{~h}, 6 \mathrm{~h}, 12 \mathrm{~h}, 18 \mathrm{~h}$ and $24 \mathrm{~h}$. The liver sections were stained with H/E and observed with a $10 \mathrm{X}$ objective. Arrow heads (Orange): Vesicular steatosis/fatty accumulation; (Dark Red): Extensive hemorrhagic necrosis; (Green): Mild/patchyportal hepatitis. TC: Tetracarpidium conophorum 
index of hepatocellular injury in rats, while ALT elevation is more associated with the necrotic state [38]. Serum ALP and $\gamma$-GT, are important enzymes in assessing obstructive liver injury $[39,40]$, and were found to be significantly elevated in $\mathrm{CCl}_{4}$-treated rats. The administration of methanol extract of T. conophorum seeds, however, was able to attenuate the toxic effects of $\mathrm{CCl}_{4}$ by reducing the increased activities of the serum enzymes (AST, ALT, ALP, $\gamma$-GT) and total bilirubin at both $250 \mathrm{mg} / \mathrm{kg}$ and $500 \mathrm{mg} / \mathrm{kg}$ in a dose-dependent manner. This is in agreement with Eidi et al. [41], who stated that administration of walnut leaf extract (ranging from 0.2 to $0.4 \mathrm{~g} / \mathrm{kg}$ body weight) significantly lowered serum ALT, AST and ALP levels in the $\mathrm{CCl}_{4}$-treated rat. Post-treatment of rats with the extract at 250 and $500 \mathrm{mg} / \mathrm{kg}$ respectively after $\mathrm{CCl}_{4}$ administration significantly restored liver damage in a dose-dependent manner. Similarly pre/post-administration of standard silymarin also reduced the toxic effect of $\mathrm{CCl}_{4}$ induced liver damage.

Oxidative stress induced by $\mathrm{CCl}_{4}$ in rats in this study show a significant decrease in the antioxidant enzymes. Oral administration of the methanol extract of T. conophorum seeds gave rise to increase in the antioxidant parameters investigated in this study. The increases were observed significantly at both 250 and $500 \mathrm{mg} / \mathrm{kg}$ extract for catalase, superoxide dismutase, reduced glutathione and glutathione peroxidase, except glutathione S- transferase when compared with $\mathrm{CCl}_{4}$ treated rats. Antioxidants have been observed to exert their action in vivo by inhibiting the generation of reactive oxygen species by suppressing the CytP450 bioactivation of chemicals and drugs to reactive metabolites [42]. Antioxidants also carry out their mechanism of action by directly scavenging free radicals, a process known as mopping up, by up-regulating the expression of the genes coding for SOD, CAT, glutathione peroxidase and glutathione reductase $[43,44]$. This may be achieved by activating nuclear transcription factor erythroid-derived 2-like 2 (Nrf2), a transcriptional regulator that controls the expression of genes involved in oxidative defense. Mechanistically, Nrf2 is inactive in the cytoplasm due to the formation of a complex with its inhibitor Keap-1 [45]. Following the release of Keap-1 from complex induced by oxidative stress, Nrf2 is translocated to the nucleus, where it binds to promoters containing antioxidant response elements (AREs), resulting in the transactivation of the respective genes for antioxidant enzymes [45]. The methanol extract of $T$. conophorum seeds, known for its antioxidant activity, may increase the levels of phosphorylated AKT and extracellular signal-regulated protein kinase (ERK) in hepatocytes, increasing Nrf2 phosphorylation at serine or tyrosine residues, which help in the dissociation of the Nrf2/Keap1 complex that maintains Nrf2 in the cytosol. This increases the translocation of Nrf2 to the nucleus where it binds to the antioxidant responsive element (ARE) to increase the expression and activity of GPx, GST, and GR, resulting in a decrease of the oxidative stress status [46]. Carbon tetrachloride administration significantly induced lipid peroxidation, a marker of oxidative stress. However, administration of the methanol extract of $T$. conophorum seeds led to significant reduction of lipid peroxidation. This was in agreement with Theophile et al. [47], who posited that plants with antioxidant activities could be protected from oxidative damage.

\section{Conclusion}

The methanol extract of $T$. conophorum seeds at doses up to $500 \mathrm{mg} / \mathrm{kg}$ was able to ameliorate the biochemical changes and injuries associated with the effect of $\mathrm{CCl}_{4}$ poisoning which could be attributed to the presence of phytochemicals and antioxidant activities. It could therefore be suggested based on these findings that methanol extract of T. conophorum seeds possesses protective effect against $\mathrm{CCl}_{4}$-induced hepatotoxicity through its antioxidant mechanism of action.

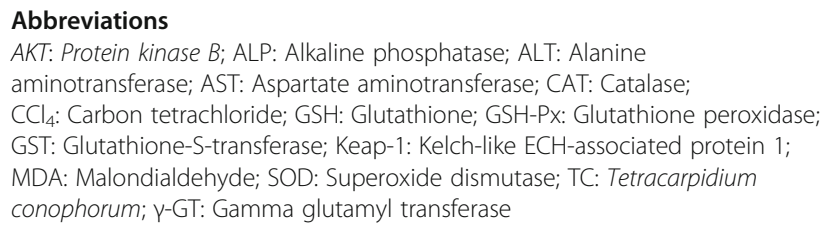

\section{Acknowledgements}

I appreciate Mr. Keke Collins Obinna, Miss Blessing Titus and Osazee Imasuen for providing technical services.

\section{Funding}

The work was supported by Tertiary Trust Fund, University of Benin to Oriakhi Kelly, Department of Medical Biochemistry, School of Basic Medical Sciences.

\section{Authors' contributions}

Professor Patrick.O. Uadia designed the experiments, Dr. Ikechi.G. Eze prepared and interpreted the liver histology slides and Dr. Kelly Oriakhi carried out the experimental bench work, analysed, wrote the manuscript and interpreted the data. All authors read and approved the final manuscript.

\section{Ethics approval}

The study protocol was submitted to and approved by Institutional Animal Ethics Committee of the Department of Pharmacology, University of Benin. The handling of the animals was in accordance with the principles of laboratory animal care. NIH publication No. 85-23, Revised 1985.

\section{Consent for publication}

Not applicable.

\section{Competing interests}

The authors declare that they have no competing interests.

\section{Publisher's Note}

Springer Nature remains neutral with regard to jurisdictional claims in published maps and institutional affiliations. 


\section{Author details}

'Department of Medical Biochemistry, School of Basic Medical Sciences, University of Benin, Benin City, Nigeria. '2Department of Biochemistry, Faculty of Life Sciences, University of Benin, Benin City, Nigeria. ${ }^{3}$ Department of Anatomy, School of Basic Medical Sciences, University of Benin, Benin City, Nigeria.

Received: 17 January 2018 Accepted: 7 August 2018

Published online: 16 October 2018

\section{References}

1. Juza RM, Pauli EM. Clinical and surgical anatomy of the liver: a review for clinicians. Clin Anat. 2014:27:764-9.

2. Slater TF. Free radical mechanisms in tissue injury. Biochem J. 1984;222:1-15.

3. Raucy JL, Kramer JC, Lasker JM. Bioactivation of halogenated hydrocarbons by cytochrome P450 2E1. CRC Crit Rev Toxicol. 1993;23:1-20.

4. Weber LW, Boll M, Stamp FA. Hepatotoxicity and mechan- ism of action of haloalkanes: carbon tetrachloride as a toxicological model. Crit Rev Toxicol. 2003;33(3):105-36.

5. Mehendale HM, Roth RA, Gandolfi RA, Klaunig JE, Lemasters JJ, Curtis LR. Novel mechanisms in chemically induced hepatotoxicity. FASEB J. 1994;8: 1285-95.

6. Boll M, Weber LW, Becker E, Stampfl A. Mechanism of carbon tetrachloride induced hepatotoxicity. Hepatocellu- Lar damage by reactive carbon tetrachloride metabolites. Z Naturforsch. 2001;56(7-8):649-59.

7. Sevanian A, Ursini G. Lipid peroxidation in membrane and low-density lipoproteins: similarities and differences. Free Rad Biol Med. 2000;29:306-11.

8. Gallucci RM, Simeonova PP, Toriumi W, Luster MI. TNF-a regulates transforming growth factor-a expression in regenerating murine liver and isolated hepatocytes. J Immunol. 2000;164:872-8.

9. Gruebele A, Zawaski K, Kaplan D, Novak RF. Cytochrome P450 2E1- and cytochrome P450 2B1/2B2-catalyzed carbon tetrachloride metabolism: effects on signal transduction as demonstrated by altered immediate-early (c-Fos and c-Jun) gene expression and nuclear AP-1 and NF-kB transcription factor levels. Drug Metabol Disp. 1996;24:15-22.

10. Bak J, Je NK, Chung HY, Yokozawa T, Yoon S, Moon JO. Oligonol ameliorates $\mathrm{CCl}_{4}$-induced liver injury in rats via the NF-Kappa B and MAPK signaling pathways. Oxid Med Cell Longev. 2016;1:1-12.

11. Nieto N, Dominguez-Rosales JA, Fontana L, Salazar A, Armendariz-Borunda J, Greenwel P, Rojkind M. Rat hepatic stellate cells contribute to the acutephase response with increased expression of alpha1(I) and alpha1(IV) collagens, tissue inhibitor of metallo-proteinase-1, and matrixmetalloproteinase-2 messenger RNAs. Hepatol. 2000;33:597-607.

12. Lee KS, Buck M, Houglum K, Chojkier M. Activation of hepatic stellate cells by TGF alpha and collagen type I is mediated by oxidative stress through cmyb expression. J Clin Invest. 1995:96:2461-8.

13. Karou D, Dicko MH, Simpore J, Traore AS. Antioxidant and antibacterial activities of polyphenols from ethnomedicinal plants of Burkina Faso. Afri J Biotechnol. 2005;4:823-8.

14. Wolf AT, Maurer R, Glickman J, Grace ND. Hepatic venous pressure gradient supplements liver biopsy in the diagnosis of cirrhosis. J Clin Gastroenterol. 2008;42:199-203.

15. Abbas KS, Xiaogin T, Ridhwi M, Huaping Z, Barbara NT, Mark SC. Withaferin a, a cytotoxic steroid from Vassobia breviflora, induces apoptosis in human head and neck squamous cell carcinoma. J Nat Prod. 2010;73:1476-81.

16. Oke OL. Leaf protein research in Ibadan, Nigeria. University of Ibadan Press; 1995.

17. Uadia PO, Oriakhi K, Osemwenkae PO, Emokpae MA. Effect of methanolic extract of Tetracarpidium conophorum seed on haematological parameters in carbon tetrachloride administered albino rats. Nig J Biochem Mol Bio. 2012b;27(1):63-5.

18. Ajaiyeoba EO, Fadare DA. Antimicrobial potential of extracts and fractions of the African walnut-Tetracarpidium conophorum. Afr J Biotechnol. 2006;5(22): 2322-5.

19. Herbert JR, Hurley TG, Olendzki BC, Teas J, Ma Y, Ha JS. Nutritional and socioeconomic factors in reaction to prostate cancer mortality: a crossnational study. J Nat Cancer Inst. 1998:90:1637-47.

20. NIH. Guidelines for the care and use of laboratory animals. NIH publication No. 85-23, Revised 1985. 1985

21. Reitman S, Frankel S. A colorimetric method for the determination of serum glutamate-oxaloacetate and pyruvate transaminass. Am J Clin Pathol. 1957; 28:56-63.
22. Teitz NN. Determination of Gamma glutamyl Transferase. In: Fundamentals of clinical chemistry ed 3 Philadelphia, W. B Saunders Co: 1987; pg 391.

23. Kochmar JF, Moss DW. Determination of alkaline phosphatase. In: Tietz NW, editor. Fundamentals of clinical chemistry. Philadelphia: W.B. Saunders and company; 1976. p. 604.

24. Tietz NW, editor. Clinical Guide to Laboratory Tests. 3rd ed. Philadelphia: W. B. Saunders; 1995

25. Jendrassik L, Grof P. Determination of direct and indirect bilirubin. Biochem Z. 1938:297:81.

26. Misra HP, Fridovich I. The role of superoxide anion in the autooxidation of epinephrine and a simple assay for Superoxide dismustase. J Biol Chem. 1972;247:3170-5.

27. Asru KS. Colorimetric assay of catalase. Anal Biochem. 1972;47:389-94.

28. Beutler E, Duron O, Kelly BM. Improved method for the determination of blood glutathione. J Lab Clin Med. 1963:61:882-8.

29. Habig WH, Pabst MJ, Jacoby WB. Glutathione-S-transferase, the first enzymatic step in mercaptroic acid formation. J Biol Chem. 1974;249:7130-9.

30. Rostruck JT, Pope AL, Ganther HE, Swanson AB, Hafeman DG, Hoekstra WG. Selenium: biochemical role as a component of glutathione peroxidase. Sci. 1973;179:588-90.

31. Varshney R, Kale RK. Effect of calmodulin antagonists on radiation induced lipid peroxidation in microsomes. Int J Rad Biol. 1990;58:733-43.

32. Buege JA, Aust SD. Microsomal lipid peroxidation. Methods Enzymol. 1978; 52:302-10.

33. Akindele AJ, Ezenwanebe KO, Anunobi CC, Adeyemi OO. Hepatoprotective and in vivo antioxidant effects of Byrsocarpus coccineus Schum and Thonn. (Connaraceae). J. Ethnopharmacol. 2010;129(1):46-52.

34. Jaishree $V$, Badami S. Antioxidant and hepatoprotective effect of swertiamarin from Enicostemma axillare against D-galactosamine induced acute liver damage in rats. J Ethnopharmacol. 2010;130:103-6.

35. Karakus E, Karadeniz A, Simsek N. Protective effect of Panax ginseng against serum biochemical changes and apoptosis in liver of rats treated with carbon tetrachloride $\left(\mathrm{CCl}_{4}\right)$. J Hazard Mater. 2011:195:208-13.

36. Waller RL, Glende EA, Recknagel RO. $\mathrm{CCl}_{4}$ and bromotrichloromethane toxicity. Dual role of covalent binding of metabolic cleavage products and lipid peroxidation in depression of microsomal calcium sequestration. Biochem Pharmacol. 1983:32:1613-7.

37. Zimmerman DJ. Drug -induced liver disease. Drugs. 1978;16(1):25-45.

38. Navarro VJ, Senior JR. Drug related hepatotoxicity. New England J Med. 2006;354:731-9.

39. Kaplan MM. Serum alkaline phosphatase-another piece is added to the puzzle. Hepatol. 1986;6:526-8.

40. Bulle F, Mavier P, Zafrani ES. Mechanism of gammaglutamyl transpeptidase release in serum during intrahepatic and extrahepatic cholestasis in the rat: a histochemical, biochemical and molecular approach. Hepatol. 1990;11: 545-50.

41. Eidi A, Mortazavi P, Moghadam JZ, Mousar P. Hepatoprotective effects of Portulaca oleracea extract against $\mathrm{CCl}_{4}$-induced damage in rats. Pharm Bio. 2014;1:1-10.

42. Uadia PO, Oriakhi K, Osemwenkae PO, Emokpae MA. Phytochemical screening and antioxidant capacity of methanolic extract of Tetracarpidium conophorum seeds. Nig J Biochem and Mol Bio. 2012a;27(1):16-26.

43. Aruoma Ol. Free radical, antioxidants and international nutrition. Asia Pasific J Clin Nutr. 1999;8(1):53-63.

44. Kamalakkannan N, Rukkumani R, Aruna K, Varma PS, Viswanathan P, Menon VP. Protective effect of $\mathrm{N}$-acetyl cysteine in carbon tetrachloride-induced liver damage. Iranian J Pharm and ther. 2005:42:118-23.

45. Martín MA, Ramos S, Granado-Serrano AB, RodríguezRamiro I, Trujillo M, Bravo L, Goya L. Hydroxytyrosol induces antioxidant/detoxificant enzymes and Nrf2 translocation via extracelular regulated kinases and phosphatidylinositol-3kinase/protein kinase B pathways in HepG2 cells. Mol Nutr Food Res. 2010;54:956-66.

46. Echeverria F, Ortiz M, Valenzuela R, Videla LA. Hydroxytyrosol and cytoprotection: a projection for clinical interventions. Int J Mol Sci. 2017;18:930

47. Theophile D, Emery TD, Desire DDP, Veronique PB, Njikam N. Effects of Alafia multiflora staff on lipid peroxidation and antioxidant enzyme status in carbon tetrachloride-treated rats. Pharmacol Online. 2006;2:76-8. 